\title{
6. Paradoxical Masculinity: James Bond, Icon of Failure
}

\author{
Toby Miller
}

\begin{abstract}
The James Bond films enact dilemmas posed by the paradoxical, split subjectivity of male spies under capitalism. Success and failure, sophistication and ignorance, knowledge and class, gender and sexuality, commercial targeting and viewing pleasure jumble together in a complex amalgam. A weird mix of hyper-bourgeois individualist, technocrat, and empty signifier, 007 can never relax, never truly know who he is, beyond being a shifting sign of impermanent state labor. His masculinity incarnates these paradoxes: often derided and celebrated for his brutality, Bond exemplifies less-than-conventional forms of life in his sexuality and identity.
\end{abstract}

Keywords:James Bond; masculinity; capitalism; hegemony; metrosexual; split subjectivity

This chapter contends that far from being the alpha and omega of the latter-day Hollywood macho man, ${ }^{1}$ James Bond has been in the vanguard of weak, commodified male beauty, and compensation for its loss: a mythic imbrication of sex, secrets, and the risible but welcome slide from an Empire to a Commonwealth of Nations. It is odd to suggest that Bond's masculinity is a paradox - that he might be an icon of failure. After all, we are told that 007 is "fit, sensual, technical, memorializing, and calculating [...] thrilling audiences in sensual stories of seduction, revelation, and calculation" (Funnell and Dodds 2015, 123). Ian Fleming boasted that he wrote the novels

1 Consider Clint Eastwood, Charles Bronson, Bruce Lee, Sylvester Stallone, Arnold Schwarzenegger, Jet Li, Vin Diesel, Bruce Willis, Chris Hemsworth, Tom Cruise, Matt Damon, Chris Evans, Chuck Norris, Jackie Chan, Jean-Claude Van Damme, Harrison Ford, Keanu Reeves, Steven Seagal, Wesley Snipes, Liam Neeson, Dwayne Johnson, or Jason Statham.

Verheul, J. (ed.), The Cultural Life ofJames Bond: Specters of oo7. Amsterdam: Amsterdam University Press, 2020 DOI 10.5117/9789462982185_CHO6 
for "red-blooded, heterosexual adults" (South Bank Show 2008) and that "all history is sex and violence" (Desert Island Discs 1963). The story lines have led latter-day statistical mavens to count the number of women 007 sleeps with in each film (described as "conquests") alongside the number of martinis downed by each lead actor (Young 2019). And consider the instructions that Roald Dahl received for the screenplay to You Only Live Twice (UK: Lewis Gilbert, 1967):

Three girls. No more and no less. Girl number one is pre-Bond. She stays around roughly through the first reel of the picture. Then she is bumped off by the enemy, preferably in Bond's arms. [...] Girl number two is antiBond. She works for the enemy and stays throughout the middle third of the picture. She must capture Bond, and Bond must save himself by bowling her over with sheer sexual magnetism. The girl should also be bumped off, preferably in an original fashion. [...] Girl number three is violently pro-Bond. She occupies the final third of the picture, and she must on no account be killed (Dahl 1967).

Asian Adventure magazine's August 1967 front cover featured a triptych representing three countries: an elderly man with tightly-squeezed features headlined as "Borneo Head-Hunters House Guest;" a stone-chiseled face on a wall signifying "Lost Cities of Cambodia;" and a still photograph from You Only Live Twice of Sean Connery in a Japanese hot tub surrounded by four women in bikini tops and briefs, one talking to him and three soaking his body. Further articulating such Orientalism, Esquire admired the film's "diving girls" and "massage girls" from the "Mysterious Orient" (Adams 1967). The Los Angeles Herald-Examiner thought its sex scenes would be "wonderful for Asian relations" ("Killing Off" 1967; Loynd 1967).

But for all that we might now construct a lineage of Bond as the first in a lengthening line of mostly Western muscle-bound action-adventure heroes, he was seen as quite another figure from the 196os onward. When Esquire (Bilmes 2015) announced in 2015 that Daniel Craig "redefined the once cartoonish secret agent as a symbol of masculinity for the modern age: embattled, conflicted, but still standing, still ready to take on the world," it was actually reiterating a venerable trope. Indeed, the ahistorical idea of Craig as the first beefcake Bond, designed for straight female and gay male spectators, is unsustainable (Williams and Flynn 2006; Cox 2015; Manganas 2019). Eva Green, Bond Girl Vesper Lynd in Casino Royale (UK/ Czech Republic/USA/Germany/Bahamas: Martin Campbell, 20o6), may have spoken truth to power in avowing that "He's the Bond Girl, Not Me" 
(quoted in Jeffries 2007), but Roger Ebert (1999) is correct that "Bond is consistently Bond: He remains recognizably the same man he was in 1962." My contention is that during that period, and indeed ever since, 007 has expressed significant changes in the political economy of masculinity, as beauty and precariousness have dueled with toil and certainty.

The seemingly irresistible, everlasting desire to extrapolate from 007 onto the world we live in is a sign that Bond exhibits that rarest of capacities: an ability to cross the normal frontiers of the semiosphere, to transcend the screen and become a mass icon of the everyday (Lotman 1996). Eduardo Galeano (2004) illustrates his classic account of and from the Global South with the observation that multinational corporations "seat and unseat kings and presidents, finance palace plots and coups d'etat courtesy of innumerable generals, ministers, and James Bonds under their command [my translation]." For Jean Baudrillard $(1998,171)$, the mythic hyper-competent US businessman is "part James Bond, part Henry Ford." Roger Moore opened the 1992 United Nations Conference on Environment and Development ("the Earth Summit") in Rio de Janeiro by saying that as per his time as Bond, he was opposed to "evil men trying to destroy our planet" (quoted in Harré et al. 1999, 17). For Ralph Miliband (1969, 226), Bond was one of the quintessential "paragons of anti-Communist virtues," and MI6 reportedly delights in the franchise's free advertising, which assists in recruitment (Cain 2019).

Such reference points in real life are legitimized by Fleming's work in wartime intelligence and later drawing-room liaisons with trans-Atlantic security elites (Moran and McCricken 2019). And in his travel writing and fiction, nothing but the 'finest' actual tobacco, coffee, and cars sufficed. The obsession with prestigious brands so evident in the novels and films - one to develop character, the other to defray production costs - and the books' grief over the advent of a welfare state and the decline of empire, are profound (Bennett and Woollacott 1987). Perhaps only Alvin Toffler (1971) regarded the series as an empty fad, destined for the trash. How wrong could a lapsed Trot/Reagan fanatic be?

On the left, both the books and the films are routinely—and rightly—held up as significant contributors to, and symptoms of, imperialism, sexism, Orientalism, class hierarchy, and jingoism; even as the first form of mass pornography (Baron 1994, 69-70; Bold 1993; Drummond 1986, 66-67; Moniot 1976, 29; Denning 1992, 225; Funnell 2015). He was berated for displaying "the sadism of a schoolboy bully, the mechanical two-dimensional sex-longings of a frustrated adolescent, and the crude snob-cravings of a suburban adult" (Johnson 1958).John le Carré (Intimations 1966) called Bond an "international gangster" lacking "all political context" and driven by a "consumer-goods 
ethic:" a person for whom ordinary objects were transformed by the magic of espionage to induce materialistic pleasure. Penelope Gilliatt (1963) worried that the films' "brutal flippancy" was "a new voice of the age." For Pauline Kael (1966), they summed up Hollywood: a successful but empty place; technology without art. Warming to the theme of hyper-consumerism and snobbery, Manny Farber $(1971,161)$ referred to Thunderball (UK: Terence Young, 1965) as "a catalogue of posh-vulgar items for licentious living." Theodore Roszak $(1969,216)$ regarded 007 as the embodiment of technocracy, maintaining a "clinical cool while dealing out prodigious sex or sadistic violence." For Stuart Hall (2010, 303), Bond villains represented a casual yet marked and purposive racism. And looking back on 007's first half-century on film, Jane Martinson (2012) said feminists were "sick of a long-running multibillion-pound franchise that left a series of beautiful women as little more than roadkill in the path of the spy we never loved."

Reactionary critics see things differently. Vincent Canby (1971) adored this "steadfast agent for the military-industrial complex, a friend to the C.I.A. and a triumphant sexist." His latter-day fellow-travelers lament that the US is not a nation of Bonds. Breitbart is relieved that 007 can "survive a miserable trend of male feminization" (Meyers 2014) and horrified by "the truly awful idea of a female or gay James Bond" (Nolte 2019). The American Conservative luxuriates that "Bond's Britain is relevant, wealthy, and influential, still a beacon of Western ingenuity," regretting that "today's man, coerced into believing in his own emasculation, would introduce himself to a lesbian named Pussy Galore by saying: 'I respect your lifestyle choice.' When James Bond met a lesbian named Pussy Galore, he slept with her" (Tippins 2012). The Federalist glorifies 007 as "the quintessential alpha male" who "is all about guarding the perimeter and protecting the group" and deems it "exhilarating for a woman to bring the alpha male to his knees through her feminine wiles." This is apparently "the height of eroticism" (McAllister 2017). The magazine is horrified by the prospect of what it calls "a lefty's dream and a Bond fan's nightmare: a female-helmed James Bond” (Enck 2019), preferring hyper-masculine "decisiveness, his willingness to take a life without remorse in the cause of queen and country" (Tracinski 2015). The Telegraph lauds Bond as "masculinity's last Hollywood outpost" (Daubney 2015) while the Daily Mail avows that " 007 may be a sexist dinosaur, but I still prefer it when a granite-tough alpha male saves the world" (Epstein 2017).

I think something else has been going on, beyond what these accounts allow; something more contested and complex. Returning to the right's reactions, the libertarian Cold War pop philosopher and idol of contemporary US conservatism Ayn Rand $(1975,138)$ adored the 007 books for their unabashed 
Romanticism and inspirational transcendence. But she was troubled that the film franchise was laced with "humor intended to undercut Bond's stature, to make him ridiculous." Her concerns were in keeping with Fleming's lament for the passing of "real" heroism (Hellman 1962), itself a typical complaint of the "war bores" so prevalent among upper-crust Englishmen after 1945 ("War Bores" 2004). It is significant in this regard that the Bond actors were some distance from the image of a highly-educated scion of the ruling class. The box below shows that none of them were the upper-crust Englishman of official fantasies. Put another way, there has routinely been a publicly visible, audible, and even widely-promoted, gap between the ideal they embodied and the men they were (Cox 2014).

Sean Connery: A working-class Scot who was a barrow and dairy transport worker and junior horseman at the Corstorphine Dairy, sailor, naked male model, and bodybuilder ("Connery's Milkman" 2005; "Before" 2007; http:// picphotos.net/sean-connery-as-a-bodybuilder-http-www-ebay-com-itmsean-connery/).

George Lazenby: A working-class, rural Australian whose mother worked in a department store and father on the railways, he rose to prominence in 1961 by getting a speeding ticket in Canberra (" $£ 45$ Fine" 1961), and became a used-car salesman and male model (https://www.youtube.com/ watch?v=WQxcoGOhnts). Co-star Diana Rigg described him as "ill-equipped" (https://www.youtube.com/watch?v=QiRaiidtTYQ).

Roger Moore: The son of an English policeman (McGrath 2012) who matriculated into modeling knitwear and portraying a wide-eyed gambler on network television (https://www.pinterest.com/pin/109001253455220364/; https://lapancetadehojita.blogspot.co.uk/2011/10/roger-moore-maverick-serie-tv.html).

Timothy Dalton: A Welshman whose father was an advertising man and mother an Irish-Italian American ("Timothy" 2013).

Pierce Brosnan: The Irish immigrant son of a carpenter and nurse who became a flame-eating busker ("Pierce" 2003).

Daniel Craig: A middle-class Englishman of aristocratic lineage whose mother was an art teacher and father a publican (La Monica 2006; “John” 2016).

In keeping with the style revolution of the 1960 s and a new generation formed from youth culture rather than tradition, some progressive voices find pleasure as well as pain in Bond. Ken Adam (South Bank Show 2008) recalls this as a time "when the British took off their handcuffs and said: 'Fuck, the Empire doesn't exist any longer. Now, we will take over.'” Janet Thumim (1992) interprets Goldfinger (UK: Guy Hamilton, 1964) as a paean 
to "personal liberation [...] privileging the young and the new" by blurring espionage with comedy; unpacking secrets is less important than the work of spectacle. And the equal legitimacy of male and female extra-marital desire lives contradictorily within Bond's violent patriarchal attitudes. Despite his sexism, the series opened a world for some women where sex was about pleasure, not commitment; fun, not family; action, not inertia; taking, not waiting (Douglas 1994; Miller 2001; Cox 2015). These paradoxical responses from both left and right are present throughout espionage fiction.

\section{Espionage}

Espionage involves surreptitiously conveying information about a country, company, or union to its enemy or rival. It is to do with theft, secrecy, trust, and lies. Espionage fiction's nexus of spectacle and violence has led to accusations that it models anti-social conduct, heroizes the capitalist state, delights in base consumerism, and endorses covert government action. Loyalty, patriotism, and the mundanity of public employment are re-forged as plays with death, doom, and style. The mystery concerns the enemy's reasons, allies, and methods-plans devised and executed by a geopolitical opponent that are foiled in the lonely hour of the last instance by a lone operative, thanks to superior beauty, physique, ingenuity, and technology.

Ernest Mandel $(1984,61-62,65)$ ties the genre's popularity to the split subjectivity produced by mass-consumption capitalism. Superheroes emerge with the development of a bourgeoisie: mounting mechanization, diverse commodity production, hyper-consumerism, and increasingly alienated populations. He argues that the search for identity is a necessary process for fiction produced in such societies, where individuals are divided amongst a variety of selves: workers, buyers, and capitalists. As proprietors of homes and consumables, they uphold and even materialize laws of ownership, of both objects and people. But as citizens, they are concerned with the general good rather than their own. And as sexual subjects, they are driven by needs that take them beyond reason, the family, and property.

Spy stories enact the dilemmas posed by this contradictory subjectivity and reference law and order, the where and why of sovereignty, in a physical, material way, via the daily actions of secret agents acting as delegates of a people, monarchy, or military. The arbitrariness of this delegation, and its reliance on instant decision and action, is paradoxical. Loading up clandestine operatives with power and responsibility, and hence signing away the right to democracy, makes the myth of bourgeois society—popular 
endorsement of overt governmental processes through the publicly-ratified rule of law - unsustainable. Binary divisions between good and evil, police and felon, spy and counter-spy, West and East, become unstable, and a grudging respect and recognition of mutuality and doubling may even appear (Mandel 1984, 65, 122). How hegemonic is Bond, given varying responses to him from left and right, the slide between his on- and off-screen personae, and Mandel's account? Is he a hegemonic figure?

\section{The Paradoxes}

The intellectual lineage of hegemony lies in Antonio Gramsci's account of a contest of meaning in which a ruling class secures approval of the social order by making its power appear normal and natural. Ordinary people give "spontaneous' consent" to the "general direction imposed on social life by the dominant fundamental group." Each society contains old cultural meanings and practices, no longer dominant but still influential, and emergent ones (Gramsci 1978, 12). Raewyn Connell (1995, 185-99; 1993, 602) applies this notion of consent-through-incorporation to gender, articulating the expansion of North Atlantic commercial republics across the world to contemporary ethnography and political economy. The resultant hegemonic masculinity makes Western-European and North-American white male sexuality isomorphic with power: dominant men seek global dominion and desire, orchestrated to oppress women and marginal men. One might regard espionage fiction as part of obtaining Gramscian consent, because it glamorizes the work of spies as entertainment, patriotism, and raison d'état, while Bond's image as an unquestioningly loyal Englishman, serial philanderer, gadget man, and fanatic for the high life appears to fit Connell's analysis.

The series is definitely guilty as charged (and valorized) for its sexism, racism, imperialism, and consumerism - but frequently in a chaotic manner that is more complex and contradictory than critical or welcoming accounts of a colonialist, snobbish, or phallic hero will allow. In conversation with Raymond Chandler, Fleming disclosed that he thought of Bond as a "blunt instrument wielded by a government department who would get into bizarre and fantastic situations [...] he's always referred to as my hero. I don't see him as a hero myself. On the whole I think he's a rather unattractive man" (Fleming and Chandler 2014, 31). Alexander Cockburn $(1987,30-31)$ suggests that 007 incarnates a "postimperial fantasy:" the first screen action hero to embody and address the new, fragile pleasure of the 
commodity, an environment in which both Bond and those he encounters are "mundane objects of desire." Small wonder that Christopher Hitchens (2006) discerned "the penis envy of a declining power" and Eric Hobsbawm (1995) saw characters "compensating for their country's decline." As Ernst Stavro Blofeld rather wonderfully tells 007 in Diamonds Are Forever (UK: Guy Hamilton, 1971), "Your pitiful little island hasn't even been threatened."

A frequently stricken figure, Bond's emotions are intense, his drinking dipsomaniacal, and his body routinely reduced. That body-so often both shaken and stirred, by people, technologies, and events beyond his ken-is a perilous means of being known and of losing authority, a site of the potentially abject that must be objectified as a sign of self-control and autotelic satisfaction. Its stark movements between patriarchal power and limp failure embody the long crisis of a seemingly victorious Atlantic masculinity that began after 1945 with soldiers' return from the front to a crumbling economy and empire in Britain and new gender relations in the US, occasioned by the wartime economic mobilization of women followed by peacetime's suburbanization of the population. Such movements intensified in the face of both countries' progressive deindustrialization from the 196os onward, the rise of the services sector, and new developments in the political economy of looking (Miller 2008). Those social, economic, and cultural shifts impelled the slow move that has made the male body the object of routine public ocular dissection. They have also increased options for toying with its symbolism. Commodification through niche targeting has increasingly identified men as objects of desire for gay male and straight female viewers (Miller 2001). I hope to illustrate this paradox by focusing on two of the long-lasting Bonds, Sean Connery and Pierce Brosnan.

\section{Connery}

As the splendidly-named Product Digest put it at the time, Connery was chosen after a thorough "search for the exciting figure who was designed to set masculine pulses hammering and feminine hearts throbbing" ("Dr. No" 1963). The filmmakers cast him knowing full-well that he was not the ruling-class figure of the novels, in the hope that he would appeal to straight women and encourage cross-class identification by men (Broccoli with Zec 1998, 171). Producer Albert Broccoli (quoted in Barnes and Hearn 1998, 20) called this "sadism for the family." Connery signaled the end of traditional ruling-class British confidence and a new cross-class allure and masculinity. This was part of an emergent style: the first Sunday Times magazine color supplement (1962) featured Mary Quant clothing, worn by Jean Shrimpton 
and photographed by David Bailey; a state-of-the-nation essay on Britain; and a Bond short story. The inaugural Observer equivalent included fashion from France and stills from the forthcoming 007 movie (Booker 1969, 49, 238). Connery's Bond, then, offers a complex transcendence from the ties of origin via commodities and sex, without any drive towards accumulating power and authority. He is the drifter in a tux that rarely remains pristine for long. His body bears the signs of social stratification, but never remains stable or in one place long enough to adopt the mantle of patriarchy through soil, blood, or home. Connery was frequently criticized as a wuss, in keeping with the notion that he embodied the welfare state's weak-kneed, decadent cosseting that was supposedly losing an empire (Anez 1992). Cyril Connolly's 1963 spoof "Bond Strikes Camp" found M coming out as gay and Bond a cross-dresser. ${ }^{2}$

Following a "short, sharp exploitation campaign" (Houston 1964b, 176), Dr. No (UK: Terence Young, 1962) proved extremely popular. Critics, however, were mostly negative. Monthly Film Bulletin complained that the film "misses the genuine sadistic, sybaritic relish" of the novels and deemed Connery "wooden and boorish" ("Dr. No" 1962), while there was also controversy over Bond's callous execution of Professor Dent (Anthony Dawson) and his casual sexual encounter with Miss Taro (Zena Marshall) (Yule 1992, 106). As the film begins, of course, Connery hands his card to a woman (Eunice Gayson as Sylvia Trench) he meets in a club, suggesting she come up and see him some time. This is an invitation for Trench to exercise her desire-which she does, astonishing him by breaking into his apartment within the hour. He encounters her practicing golf in his rooms, attired in just a shirt. No wonder that for Susan Douglas $(1994,72)$ growing up, Dr. No was a sign that "sex for single women [could be] glamorous and satisfying."

Such sexual agency and pleasure came at a certain cost to the image of 007. Bosley Crowther (1964) suggested five decades ago that:

Mr. Bond's off-handed conquests were always open to a certain amount of doubt, a certain amount of skepticism as to how much of a Lothario he actually is. Indeed, they have often intimated a bland contempt for, or, at least, a slippery spoof of the whole notion of masculine prowess. One might question whether Bond really likes girls.

Time magazine labeled Connery a "used-up gigolo" in the wake of $D r$. No (quoted in Barnes and Hearn 1998, 16), Newsweek condemned him as of

2 When asked whether James Bond would sleep with another man in the line of duty, Daniel Craig replied: "No. Kill him and then seduce him" (quoted in Orr, 2008). 
interest solely to "cultivated sado-masochists" (quoted in Anez 1992, 314), and many US magazines objectified him mercilessly by listing his bodily measurements (Dore 1996, 11). As far as the New Republic was concerned, Bond was "stupid. [...] His only genius lies in an infunite capacity for taking pain" (Grella 1964, 17). Connery was frequently mauled for his lack of vim and vigor, the very departures from muscular Christianity and white leadership supposedly afflicting the Britain that Fleming abjured.

Across ideological and geographical spectra came commensurate critiques from the German Democratic Republic's Communist Party youth paper, Junge Welt, and the Vatican City's L'Osservatore Romano, which discerned "a dangerous mixture of violence, vulgarity, sadism and sex" (Sann 1967, 34; L'Osservatore quoted in "Church Says" 1965). Britain's Daily Worker noted an "appeal to the filmgoer's basest instincts" and "perversion." The Spectator deemed the film "pernicious." Films and Filming called the "sex and sadism" a "brutally potent intoxicant," deriding Bond as a "monstrously overblown sex fantasy of nightmarish proportions" who was "morally [...] indefensible" and liable to produce "kinky families" (quoted in Barnes and Hearn 1998, 16-17, 26-27; Smith and Lavington 2002, 22).

But Penelope Houston (1964a) suggested that Goldfinger "converts Bond into a human equivalent of the cat in the Tom and Jerry cartoons, with the same ghastly resilience." In short, it was obviously a joke, not least thanks to Ken Adam's enormous, lovingly-detailed, excessive set designs. Steel, concrete, and gold organized life through power in monumental form-virtual memorials to authority and control that always end in pieces. And the jokes undermined 007. "Why do you always wear that thing?," inquires a woman of Connery's shoulder-holster in the pre-credits sequence of Goldfinger. His reply, "I have a slight inferiority complex," illustrates the mutability of his sexuality. And the exchange bespeaks a gratuitous self-confidence: he lets go of the gun and is subsequently exposed to peril. Variety rather straightforwardly called this "making an arrogant pass at a chick" ("Review: Goldfinger" 1963); but it was more than that.

Goldfinger puts Connery's body on display, notably in a rather alarming terry-toweling jump-suit. This is "major beefcake," retrospectively described by the Guardian as akin to the "revenge" of a "feminist art director" for the film's almost-casual sexism (Bradshaw 2007). For the New York Daily News' Wanda Hale (1964), Connery exuded "animal magnetism with that graceful panther walk and baring of the teeth in that slow smile" but was a "joke superman" ("Goldfinger" 1964). A sequence in bed with Jill Masterson (Shirley Eaton) is initially characterized by smart-ass conduct during a phone call where Bond tells a CIA agent that he cannot meet immediately because 
"something big's come up." But this is followed by defeat- 007 is knocked senseless just as he shows he's an old fogey by deriding The Beatles. Then Masterson is drowned in gold paint. Baudrillard $(1993,105)$ interprets her dead body as the triumph of the phallus over femininity through the blocking of her pores. But it was equally a sign of Bond's repeated, hapless failure.

His "masculinity" is directly at risk in the near-castration scene, when Connery is taunted by Auric Goldfinger (Gert Fröbe) while an industrial laser cuts through wood and metal towards his spread legs. 007's muscles visibly tense, the two men engage in some badinage, and a close-up on Bond's face evidences further concern. He looks between his legs and across the room in a series of reverse shots with Goldfinger. John Barry's three-minute musical sequence sustains and repeats, "with characteristic punctuation from the xylophone, an F-minor added-second chord." As the laser heads for 007's groin, violins provide "an eight-note motif, harmonized by the same chord" that crescendos many times before returning to the opening two notes of the previous motif, which also repeats itself (Brown 1994, 46-47). All this instability leaves Connery "a direct object of desire," caught between power, passivity, beauty, bondage, invulnerability, and fallibility (Bennett and Woollacott 1987, 162).

Thunderball finds Connery chided by Fiona Volpe (Luciana Paluzzi):

I forgot your ego, Mister Bond. James Bond, who only has to make love to a woman and she starts to hear heavenly choirs singing. She repents, then immediately returns to the side of right and virtue. But not this one. What a blow it must have been-you, having a failure.

Connery was routinely the object of the gaze in publicity for Thunderball, posing in 1966 be-suited for $G Q$ and bare-cleavaged for Life. The harbinger of a new male body on display, he showed that sexiness did not require a choice between ruggedness and style (McInerney 1996, 26, 32). But that equilibrium was contingent. Pauline Kael (1967) described Connery as "a paunchy, rather bemused spectator" in You Only Live Twice. Stephen Farber (1967) thought he looked "embalmed," while the New Yorker said Connery "seems deflated. Once dashing in himself, he has become the instrument of dashing production ideas" ("Nether" 1967). Crowther (1967) lamented in the New York Times that "[t]he sex is minimal. But, then, Bond is getting old," while Houston (1967) called 007 "an over-worked legend." Four decades later, the Guardian likened Connery's performance to "a slouching Burt Reynolds" (O'Neill 2012). As per Cockburn, Hitchens, and Hobsbawm, while You Only Live Twice is a high point of Orientalism, with Bond's body wiped 
clean by Japanese women, it is also the moment of Britain's withdrawal from East of Suez (announced in early 1968), and hence a certain recognition of a dream (and tyranny) that had faded and failed: the nation's begrudging acceptance of middle-power status, in keeping with the disasters of Suez, Kenya, Malaya, and Cyprus; the erosion of its manufacturing base; and the desire to increase domestic social spending.

By the time of Connery's return to the role in Diamonds Are Forever four years later, a homology was clearly in place between imperial decline and his own. Critics deemed 007's body too bloated and his hair piece too obvious: he "shuffles through the motions like some ageing heavyweight showboater, flirting with disaster, his toupee slipping" (Brooks 2012). Retrospectively, Empire magazine lamented the sight of "Connery ageing quickly, his hairline indeterminately assisted" (Nathan 2000). Is this an all-powerful ruling-class scion at work, with women cowering defensively? I think not. Connery's prior careers as Scottish Mr. Universe, Carnaby Street model, and Royal Court Shakespearian instance the risky, contingent intersection of body, style, action, and performance. He showed that the look of a man could transcend his class background and politesse: a postmodern figure of beautiful male commodification avant la lettre (Synnott 1990; Manning 1990, 3). But the currency of such beauty was subject to rapid depreciation.

Ever since Connery, there has been a discourse each time a new screen Bond is announced - in advertising, promotion, and the films themselvesabout returning to the darkness of the novels and the real spirit of the original 007, of a figure troubled by the fate of Britain at home and abroad as a nation supposedly coarsened by the welfare state and humiliated by the loss of empire. Bond, in other words, has always been a sign of the end of British confidence and a newly pleasurable display of masculinity, by turns weak and strong, flaccid and erect, commonwealth and imperial, institutionalized and autonomous. This is nostalgia for a lost world of colonialism; dismay at its decayed vestiges; signage of the power of cultural imperialism; and a marker of a newly objectified, available masculinity. Connery's trajectory said it all.

\section{Brosnan}

For Cedric Robinson $(1984,86)$, Bond's Cold War spy adventures signified a distinctly modern realm:

Bond dealt with a world which was geometric in form, brightly illuminated, aseptic, technologically advanced. It situated evil in an arena of civility. 
Evil was never reduced to brute force. It was intellectual, technically advanced and imaginative, scientific, architecturally innovative and capable of a global presence. Its phenomenology was the paraphernalia of the modern world.

That modernity was rocked by the erosion of the Cold War's binary oppositions and its proxy struggles that had given contour to decolonization. The 007 series actually decentered Cold War tensions - the Soviets or Chinese were there or thereabouts, and provided context, but the main enemy was always a criminal capitalist or rogue operative. Nevertheless, the fall of the Eastern bloc would have presented some dilemmas had it not coincided with intellectual property disputes over the franchise. As a consequence of that legal crisis, the James Bond film series lay dormant from 1989 to 1995 . Skepticism as to its future was rife: the series' supposed animating power was spent. What could 007 now offer (Harney 2002)?

While Brosnan had the same fitful, fateful task of others - to walk in Connery's shadow - he also needed to broker a shift from Soviet severity to Russian lawlessness. Arriving almost a quarter of century after Diamonds Are Forever, Brosnan's Bond was said to combine stylishness with an understated but ever-ready violence. This led to his celebration within hegemonic masculinity; as, for example, in the JamezBond animutations, where to be other than 007 was to be queer-and "lame" (Kendall 2007). But Brosnan was up for grabs as a sexual object. In its review of GoldenEye (UK/USA: Martin Campbell, 1995), the Washington Post named him a "programmed cover boy" (Howe 1995), while Rolling Stone advised readers that Tomorrow Never Dies (UK/USA: Roger Spottiswoode, 1997) featured "[l] ess an actor than a model" (Travers 1997). Janet Maslin (1999) thought he barely "entered the land of the living" but CNN avowed that "he'll have the ladies turning out in swooning droves" (Buckland 1995) and the Seattle Times' Moira Macdonald (2002) found him "so devilishly handsome he really should come with a warning label."

Brosnan's 007 and his "permanent come-hither squint" (Morris 1999) coincided with the emergence of the "metrosexual," a term coined in the mid-199os by queer critic Mark Simpson (1998), who encountered "the real future" and found "it had moisturized." Historically, male desire for women has been over-legitimized and female and male desire for men under-legitimized. ${ }^{3}$ The advent of metrosexuality represented a major shift in power relations, with men subjected to new forms of governance and 
commodification. Metrosexuals endorsed equal-opportunity vanity through cosmetics, softness, women, hair-care products, wine bars, gyms, designer fashion, wealth, the culture industries, finance, cities, cosmetic surgery, and deodorants. Happy to be the object of queer eroticism and committed to exfoliation and web surfing, these newly feminized males blurred the visual style of straight and gay - and were supposed to be every fifth man in major US cities. Single straight men embarked on what the New York Times called "man dates," nights out together without the alibis of work and sport or the props of televisions and bar stools - although Yanquis shied away from ordering bottles of wine together (Miller 2008). Metrosexuality was embraced by Western European, Australian, South Asian, Latin American, East Asian, and US marketers, who regarded the emergent creature as "having the strength to be true to oneself" rather than simply being a vain cat. Based on its rapid diffusion, acceptance, and national usage, "metrosexual" was declared word of the year for 2003 by the American Dialect Society - ahead of "weapons of," "embed," and "pre-emptive self-defense." Euromonitor's 2006 report on the phenomenon was entitled The Male Shopping Giant Awakes. ${ }^{4}$

Brosnan was often taken to represent just such politically-correct masculinity: polished, witty, well-dressed, and finely-groomed. Publicity shots generally showed him looking boldly into the camera in a tuxedo, with not a hair out of place. His narrow emotional range could be interpreted as coolness. Janet Maslin (1995) welcomed Brosnan as a "coffee-bar James Bond: mild, fashionable and nice in a very go's way [...]. The best-moussed Bond [...] a fabulous clothing model." There are obvious connections to Connery's paradoxical mixture of beauty, vulnerability, and violence. Although Brosnan supposedly epitomized metrosexuality through his "italicized good looks" and "restrained air of machismo" (Ellen 2002), given the softness of his beauty, the elegance of his approach, and the style of his habiliments, he was also hailed as the opposite of the metrosexual in his devil-may-care attitude. I have found debates about Brosnan as metrosexual versus non-metrosexual in sources stretching from Britain to Malaysia to Ecuador to the US to Spain to Ireland to Mexico to India. Some ask whether he was the first metrosexual Bond; others categorize him as the last hold-out before Craig took over (Torregrossa 2007; Khoo 2006; Harris 2005; Majors 2005; "Los ubersexuales" 2007; Ruiz and Santander 2006; Reynolds 2007; Guevara 2006; Zakaria 2004; Tippins 2012). In the UK, the Daily Mirror, a working-class leftist paper, plumped for Brosnan as anti-metrosexual (Moodie and Lawler 2008), while the Daily Mail, a working-class conservative rival nationally and gossipy T\&A 
web site globally, saw him as the acme of metrosexuality (Newland 2006). Meanwhile, the Daily Telegraph, a ruling-class conservative paper, defined him as post-metrosexual (Goswami 2005). In the tradition of bourgeois Yanqui journalism, the New York Times bet each way (Menkess 2006).

But Brosnan's time came to an end, as all such commodified beauty must do. Maitland McDonagh (1996) predicted he would "last a good half-dozen films before his waist thickens and his solid good looks begin to slide." And with The World is Not Enough (UK/USA: Michael Apted, 1999), the Guardian warned that Brosnan was "ageing and cragging up" (Bradshaw 1999), the New York Post said "his boyish face ages and his frame fills out" (Foreman 1999), and the Washington Post observed that he was "starting to look a tad long in the tooth" (Howe 1999). Manohla Dargis (2002) felt obliged to note that in Die Another Day (UK/USA:Lee Tamahori, 2002), Brosnan was "a very fit 49 year-old actor who's nonetheless 49." Then it was over. The Daily Mail explained that the decision to end his time in the role was made following "pictures taken at a family barbecue [...] in which he betrayed signs of middle-age spread" ("Is Brosnan" 2004). This is the kind of cruel bodily scrutiny supposedly reserved for patriarchal surveillance and misogyny. In time, it happens to every Bond.

\section{Conclusion}

As embodied by Sean Connery and Pierce Brosnan, 007's masculinity enacts dilemmas posed by the paradoxical, split subjectivity identified by Mandel. Success and failure, sophistication and ignorance, knowledge and class, gender and sexuality, commercial targeting and viewing pleasure jumble together in a complex amalgam that is more conflictual than theories of hegemonic masculinity perhaps allow. A weird mix of hyper-bourgeois individualist, technocrat, and empty signifier, 007 can never relax, never truly know who he is, beyond being a shifting sign of impermanent state labor.

The secret agent is a member of the precariat, that latest breed of postindustrial person, with high levels of educational attainment, great facility with cultural and communications technologies and genres - and a very uncertain future. Spies are protean, pacey, and problematic, from their alpha to their omega. They are the ultimate flexible subjects: empty and ready to obey, depthless and prepared to innovate. That model is reworked time and again, but is far from being a straightforward assertion of brute maleness or elite taste. Rather, it encompasses Mandel's split subject, the vulnerable beauty of traditional femininity, and the uncertain membership of the precariat. And its name is Bond. 


\section{Works Cited}

“£45 Fine in Traffic Case Re-Hearing." 1961. Canberra Times, December 15, 61.

"Before He was Bond: Semi-Nude Portrait of Sean Connery Reveals His Early Promise." 2007. The Daily Mail, October 25, http://www.dailymail.co.uk/tvshowbiz/ article-489617/Before-Bond-Semi-nude-portrait-Sean-Connery-reveals-earlypromise.html.

"Church Says No, No to “No"." 1965. Los Angeles Times, May 19.

“Connery's Milkman Wages Revealed." 2005. BBC News, November 21, http://news. bbc.co.uk/1/hi/scotland/4457708.stm.

"Dr. No." 1962. Monthly Film Bulletin, October, 135.

“Dr. No." 1963. Product Digest, April 3, 785.

"Goldfinger." 1964. Monthly Film Bulletin, October, 149.

"Is Brosnan Too Old to Be 007?.” 2004. The Daily Mail, February 9, http://www. dailymail.co.uk/tvshowbiz/article-207653/Is-Brosnan-old-oo7.html.

"John Cleese Declares Daniel Craig Too Short for James Bond." 2016. The Daily Telegraph, February 22, http://www.dailytelegraph.com.au/entertainment/sydneyconfidential/john-cleese-declares-daniel-craig-too-short-for-james-bond/ news-story/b4de208ao4feb254adb9514246e56of6.

“Killing Off Bond." 1967. Esquire, March, 74-85.

"Los ubersexuales jubilan a los metrosexuales en el mundo." 2007. El Comercio, July 29.

"Nether Villainy." 1967. The New Yorker, June 24, 74.

"Pierce Brosnan: Questions from the Floor." 2003. The Guardian, March 18, https:// www.theguardian.com/film/2003/mar/18/features1.

"Review: Goldfinger." 1963. Variety, December 31, http://variety.com/1963/film/ reviews/goldfinger-1200420642/.

“Timothy Dalton: The Bond of Colwyn Bay." 2013. The Daily Post, April 19, http:// www.dailypost.co.uk/news/north-wales-news/timothy-dalton-bond-colwynbay-2765248.

"War Bores." 2004. The Economist, October 28, http://www.economist.com/ node/3331095.

Adams, Andy. 1967. "Bond Kicks Up Furore in Japan." Asian Adventure, August, 8-15. Anez, Nicholas. 1992. "James Bond." Films in Review 43, nos. 9-10: 310-19.

Barnes, Alan, and Marcus Hearn. 1998. Kiss Kiss Bang! Bang! The Unofficial James Bond Film Companion. Woodstock: Overlook Press.

Baron, Cynthia. 1994. "Doctor No: Bonding Britishness to Racial Sovereignty." Spectator 14, no. 2: 68-81.

Baudrillard, Jean. 1993. Symbolic Exchange and Death, translated by Ian Hamilton Grant. London: Sage. 
Baudrillard, Jean. 1998. The Consumer Society: Myths and Structures, translated by C. T. London: Sage.

Bennett, Tony and Janet Woollacott. 1987. Bond and Beyond: The Political Career of a Popular Hero. Basingstoke: Macmillan.

Bilmes, Alex. 2015. "Daniel Craig is Esquire's October Cover Star." Esquire, October 21, http://www.esquire.co.uk/culture/film/news/a8782/daniel-craig-interview/.

Bold, Christine. 1993. ' Under the Very Skirts of Britannia:' Re-reading Women in the James Bond Novels." Queen's Quarterly 100, no. 2: 310-27.

Booker, Christopher. 1969. The Neophiliacs: A Study of the Revolution in English Life in the Fifties and Sixties. London: Collins.

Bradshaw, Peter. 1999. "You're Stuck in the 5os, Mr Bond." The Guardian, November 26, https://www.theguardian.com/culture/1999/nov/26/jamesbond.

Bradshaw, Peter. 2007. “Goldfinger.” The Guardian, July 27, https://www.theguardian. com/film/2007/jul/27/jamesbond.actionandadventure.

Broccoli, Albert, with Donald Zec. 1998. When the Snow Melts: The Autobiography of Cubby Broccoli. London: Boxtree.

Brooks, Xan. 2012. "My Favourite Bond Film: Diamonds Are Forever." The Guardian, September 27, https://www.theguardian.com/film/filmblog/2012/sep/27/ favourite-bond-diamonds-are-forever.

Brown, Royal S. 1994. Overtones and Undertones: Reading Film Music. Berkeley: University of California Press.

Buckland Carol. 1995. “'GoldenEye:' 007's License to Thrill Renewed.” CNN, November 21, http://edition.cnn.com/SHOWBIZ/Movies/9511/GoldenEye/review.html.

Cain, Sian. 2019. 'James Bond Still a Strong 'Recruitment Sergeant' for MI6, Says Expert.” The Guardian, May 30, https:/www.theguardian.com/books/2019/ may/3o/james-bond-still-a-strong-recruitment-sergeant-for-mi6-says-expert.

Canby, Vincent. 1971. “A Benign Bond.” The New York Times, December 18, http:// www.nytimes.com $/$ movie/review? ${ }^{\text {res }}=950 \mathrm{DE}_{5} \mathrm{D}_{10} 8 \mathrm{EF}_{34} \mathrm{BC}_{40}{ }_{2} \mathrm{DFB}_{4} 67838$ A669EDE\&partner=Rotten\%2520Tomatoes.

Connell, R. W. 1993. "The Big Picture: Masculinities in Recent World History." Theory and Society 22, no. 5: 597-623.

Connell, R. W. 1995. Masculinities. Berkeley: University of California Press.

Cockburn, Alexander. 1987. "James Bond at 25." American Film 12, no. 9: 26-31, 59.

Connolly, Cyril. 1963. Previous Convictions. New York: Harper \& Row.

Cox, Katharine. 2014. "Becoming James Bond: Daniel Craig, Rebirth, and Refashioning Masculinity in Casino Royale (2006)." Journal of Gender Studies 23, no. 2:184-96.

Cox, Tracey. 2015. “Every Woman Wants One Night With Bond.” The Daily Mail, October 26, http://www.dailymail.co.uk/femail/article-3288436/Every-womanwants-one-night-Bond-Tracey-Cox-Daniel-Craig-s-007-s-cheesy-chat-linessteamy-bedroom-antics-leave-shaken-stirred.html. 
Crowther, Bosley. 1964. "Goldfinger." The New York Times, December 22, http:// www.nytimes.com/movie/review?res=EE05 $\mathrm{E}_{7} \mathrm{DF}_{173} \mathrm{DE}_{46} \mathrm{~B}_{4} \mathrm{BC}_{4} \mathrm{~A}_{51} \mathrm{DFB}_{4} 6783$ 8F679EDE\&partner=Rotten\%2520Tomatoes.

Crowther, Bosley. 1967. "Sayonara, 007: Connery is at it Again as Whatshisname." The New York Times, June 14, http://www.nytimes.com/movie/review?res=9Co7 $\mathrm{E}_{5} \mathrm{DE} 173 \mathrm{FE}_{53} \mathrm{BBC}_{4} \mathrm{C}_{52} \mathrm{DFB} 066838 \mathrm{C6} 79 \mathrm{EDE} \&$ partner=Rotten\%2520Tomatoes.

Dahl, Roald. 1967. “007's Oriental Eyefuls." Playboy, June, 86-91.

Dargis, Manohla. 2002. "Bond's 40 But Refuses to Leave." Los Angeles Times, November 22, http://articles.latimes.com/2002/nov/22/entertainment/et-dargis22.

Daubney, Martin. 2015. “James Bond: You're a Sexist, But We Love You for It." The Telegraph, September 1, http://www.telegraph.co.uk/men/thinking-man/11836460/ James-Bond-youre-a-sexist-but-we-love-you-for-it.html.

Denning, Michael. 1992. "Licensed to Look: James Bond and the Heroism of Consumption." In Contemporary Marxist Literary Criticism, edited by Francis Mulhern, 211-29. London: Longman.

Desert Island Discs. 1963. "Ian Fleming," https://www.youtube.com/watch?v=JFSEBeOEVo.

Dore, Katherine. 1996. "Public School Playboy: The Image of James Bond in America in the Sixties." Unpublished ms.

Douglas, Susan J. 1994. Where the Girls Are: Growing Up Female with the Mass Media. New York: Times Books.

Drummond, Lee. 1986. “The Story of Bond." In Symbolizing America, edited by Hervé Varenne, 66-89. Lincoln: University of Nebraska Press.

Ebert, Roger. 1999. “Goldfinger.” Roger Ebert, January 31, http://www.rogerebert. com/reviews/great-movie-goldfinger-1964.

Ellen, Barbara. 2002. "I am the Sexiest Man in the World! I Know I Am. I Read it.” The Observer, January 13, https://www.theguardian.com/film/2002/jan/13/ features.magazine.

Enck, Paulina. 2019. "A Female 007 Leaves Bond Fans Shaken (Not Stirred), and for Good Reason.” The Federalist, July 22, https://thefederalist.com/2019/07/22/afemale-007-leaves-bond-fans-shaken-not-stirred-and-for-good-reason/.

Epstein, Angela. 2017. "I Hate to Admit it, but Women Pilots Make Me Nervous." The Daily Mail, August 16, http://www.dailymail.co.uk/femail/article-4797202/Ihate-admit-women-pilots-make-nervous.html.

Farber, Manny. 1971. Movies. New York: Hillstone.

Farber, Stephen. 1967. "Review." Film Quarterly 21, no. 1: 62.

Fleming, Ian, and Raymond Chandler. 2014. "'You Want Me to Describe How It's Done?'" Five Dials 7, 30-33.

Foreman, Jonathan. 1999. "A Strong Bond.” The New York Post, November 19, http:// nypost.com/1999/11/19/a-strong-bond-brosnan-finds-his-footing-in-007s-world/. 
Funnell, Lisa, and Klaus Dodds. 2015. “'The Man with the Midas Touch:' The Haptic Geographies of James Bond's Body." Journal of Popular Film and Television 43, no. $3: 121-35$.

Funnell, Lisa. 2015. For His Eyes Only: The Women ofJames Bond. London: Wallflower Press.

Galeano, Eduardo. 2004. Las venas abiertas de América Latina. Mexico City: Siglo XXI Ediciones.

Gilliatt, Penelope. 1963. "Laughing It Off with Bond.” The Observer, October 13, https://www.mi6-hq.com/sections/articles/history_press_frwl_observer. php3?id=03595.

Goswami, Nina. 2005. "Ken Counts on a Make-Over to Win Back Barbie." The Telegraph, October 23, http://www.telegraph.co.uk/news/worldnews/northamerica/ usa/1501322/Ken-counts-on-a-make-over-to-win-back-Barbie.html.

Gramsci, Antonio. 1978. Selections from the Prison Notebooks of Antonio Gramsci, translated and edited by Quentin Hoare and Geoffrey Nowell-Smith. New York: International Publishers.

Grella, George. 1964. "James Bond: Culture Hero." New Republic, May 30, 17-20.

Guevara, Beatriz. 2006. "Hay de hombres ... a HOMBRES.” El Expreso.

Hale, Wanda. 1964. “'Goldfinger' Exudes Fun and Sex Galore.” The Daily News, December 22, http://www.nydailynews.com/entertainment/movies/ goldfinger-better-previous-bonds-1964-review-article-1.2444241.

Hall, Stuart. 2010. Sin garantías: Trayectorias y problemáticas en estudios culturales, edited by Eduardo Restrepo, Catherine Walsh, and Victor Vich. Popayán: Envión; Lima: Instituto de Estudios Peruanos; Bogotá: Instituto de Estudios Sociales y Culturales.

Harney, Stefano. 2002. State Work: Public Administration and Mass Intellectuality. Durham: Duke University Press.

Harré, Rom, Jens Brockmeier, and Peter Mühlhäuser. 1999. Greenspeak: A Study of Environmental Discourse. Thousand Oaks: Sage.

Harris, Paul. 2005. "Metrosexual Man Bows to Red-Blooded Übersexuals." The Observer, October 23, https://www.theguardian.com/world/2005/oct/23/gender. books.

Hellman, Geoffrey T. 1962. "Bond's Creator.” The New Yorker, April 21, 32.

Hitchens, Christopher. 20o6. "Bottoms Up." The Atlantic, March, https://www. theatlantic.com/magazine/archive/2006/04/bottoms-up/304719/.

Hobsbawm, Eric. 1995. The Age of Extremes: The Short Twentieth Century, 1914-1991. London: Michael Joseph.

Houston, Penelope. 1964a. “o07." Sight and Sound 34, no. 1: 14-16.

Houston, Penelope. 1964b. The Contemporary Cinema. Harmondsworth: Penguin. Houston, Penelope. 1967. "Bond Dishonoured." Spectator, April 21, 26. 
Howe, Desson. 1995. “'GoldenEye:' Bona Fide Bond.” The Washington Post, November 17, http://www.washingtonpost.com/wp-srv/style/longterm/movies/videos/ GoldenEye.htm\#howe.

Howe, Desson. 1999. “'World:' Bond Without End.” The Washington Post, November 19, http://www.washingtonpost.com/wp-srv/entertainment/movies/reviews/ worldisnotenoughhowe.htm.

Intimations - A Question of Influences. 1966. "Malcolm Muggeridge and John le Carré.” Produced by Margaret McCall. BBC, http://www.bbc.co.uk/iplayer/ episode/poonwitb/intimations-10-john-le-carre\#.

Jeffries, Stuart. 2007. "'He's the Bond Girl, Not Me.” The Guardian, January 26, https://www.theguardian.com/film/2007/jan/26/jamesbond.

Johnson, Paul. 1958. "Sex, Snobbery and Sadism." New Statesman, April 5, 430-32. Kael, Pauline. 1966. "Marlon Brando: An American Hero." The Atlantic Monthly, March, http://www.theatlantic.com/past/docs/unbound/aandc/movies/movies4. htm.

Kael, Pauline. 1967. “Consumer Guidance.” New Republic, July 15, 27-28.

Kendall, Lori. 2007. "Colin Mochrie vs. Jesus H. Christ: Messages About Masculinities and Fame in Online Video Conversations." Proceedings of the $40^{\text {th }}$ Hawaii International Conference on System Sciences, https://www.ideals.illinois.edu/ bitstream/handle/2142/705/co?sequence $=2$.

Khoo, Rubin. 2006. "Mirl of the Moment." Star, August 8.

La Monica, Paul R. 2006. "Blond, James Blond." CNN Money, November 17, http:// money.cnn.com/2006/11/o8/commentary/mediabiz/index.htm.

Lotman, Iuri M. 1996. La semiosfera, translated and edited by Desiderio Navarro. Madrid: Ediciones Cátedra.

Loynd, Ray. 1967. "Bond-san Oriental Hijinks." Los Angeles Herald-Examiner, June 15 .

Macdonald, Moira. 2002. “James Bond is Back in 'Die Another Day.'” Seattle Times, November 22, http://community.seattletimes.nwsource.com/archive/?slug=di e22\&date $=20021122$.

Majors, Dan. 2005. “Trend Watchers Have a New Label for a Refined Man's Man: Ubersexual." Pittsburgh Post-Gazette, November 26.

Mandel, Ernest. 1984. Delightful Murder: A Social History of the Crime Story. London: Pluto Press.

Manganas, Nicholas. 2019. "Real Men: Sam Smith's Emasculation of the James Bond Theme." Celebrity Studies 10, no. 3: 436-40.

Manning, Maria. 1990. "Futile Attraction." New Statesman and Society: 12-13.

Martinson, Jane. 2012. "Is Skyfall a Less Sexist Bond Film?” The Guardian, October 30 , https://www.theguardian.com/film/the-womens-blog-with-janemartinson/2012/oct/3o/skyfall-less-sexist-bond-film. 
Maslin, Janet. 1995. “That 'Sexist, Misogynist Dinosaur' James Bond.” The New York Times, November 17, $\mathrm{C} 17$.

Maslin, Janet. 1999. "The World is Not Enough." The New York Times, November 19, http://www.nytimes.com/library/film/11199genough-film-review.html.

McAllister, D. C. 2017. "Why James Bond Should Never be a Woman." The Federalist, July 24, http://thefederalist.com/2017/07/24/james-bond-never-woman/.

McDonagh, Maitland. 1996. “GoldenEye.” TV Guide, January 14, http://www.tvguide. com/movies/GoldenEye/review/130384/.

McGrath, Nick. 2012. "Roger Moore: My Family Values." The Guardian, September 29, https://www.theguardian.com/lifeandstyle/2012/sep/29/roger-moore-my-familyvalues.

McInerney, Jay. 1996. “How Bond Saved America-And Me.” In Dressed to Kill:James Bond the Suited Hero, edited by Jay McInerney, Nick Foulkes, Neil Norman, and Nick Sullivan, 13-37. Paris: Flammarion.

Menkess, Suzy. 2006. "Past Present; Secret Agent Man.” The New York Times, March 12, http://query.nytimes.com/gst/abstract.html?res=9Fo5EoDA113EF9 31A25750CoA96ogC8B63\&legacy=true.

Meyers, Lawrence. 2014. “James Bond: Super Spy. Franchise Anchor. Icon of Masculinity." Breitbart, July 2, http://www.breitbart.com/big-hollywood/2014/07/02/ james-bond-masculine-icon/.

Miliband, Ralph. 1969. The State in Capitalist Society. New York: Basic Books.

Miller, Toby. 2001. SportSex. Philadelphia: Temple University Press.

Miller, Toby. 2008. Madeover Nation: The United States of Reinvention. Columbus: Ohio State University Press.

Moniot, Drew. 1976. "James Bond and America in the Sixties: An Investigation of the Formula Film in Popular Culture." Journal of the University Film Association 28, no. 3: 25-33.

Moodie, Clemmie, and Danielle Lawler. 2008. “James Bond in Metrosexual Makeover Shock." The Daily Mirror, April 17, http://www.mirror.co.uk/3am/celebrity-news/ james-bond-in-metrosexual-makeover-shock-303132.

Moran, Christopher R. and Trevor McCrisken. 2019. "The Secret Life of Ian Fleming: Spies, Lies and Social Ties." Contemporary British History 33, no. 3: 336-56.

Morris, Wesley. 1999. "New Bond Not Quite Enough.” The San Francisco Examiner, November 19, http://www.sfgate.com/news/article/New-Bond-not-quiteenough-3057334.php.

Nathan, Ian. 2000. "Diamonds Are Forever Review." Empire Magazine, January 1, http://www.empireonline.com/movies/diamonds-forever/review/.

Newland, Martin. 2006. “'Bond' Heralds the Return of 'Pure Pecs' Appeal." The Daily Mail, November 23, http://www.dailymail.co.uk/femail/article-418054/ Bond-heralds-return-pure-pecs-appeal.html. 
Nolte, John. 2019. "Daniel Craig Endorses Terrible Idea of Female James Bond." Breitbart, April 29, https://www.breitbart.com/entertainment/2019/04/29/ daniel-craig-endorses-terrible-idea-of-female-james-bond/.

O’Neill, Phelim. 2012. "My Favourite Bond Film: You Only Live Twice." The Guardian, October 4, https:/www.theguardian.com/film/filmblog/2012/oct/o4/ favourite-bond-you-only-live-twice.

Orr, Christopher. 2008. "James Bond, Necrophiliac." New Republic, September 21, https://newrepublic.com/article/44525/james-bond-necrophiliac.

Rand, Ayn. 1975. The Romantic Manifesto: A Philosophy of Literature, rev. ed. New York: Signet.

Reynolds, Deidre. 2007. “It's the Last Stop for Metro Man." Independent Ireland, June 21. Robinson, Cedric. 1984. "Indiana Jones, The Third World and American Foreign Policy: A Review Essay." Race \& Class 26, no. 2: 83-92.

Roszak, Theodore. 1969. The Making of a Counterculture: Reflections on Technocratic Society and Its Youthful Opposition. New York: Anchor Books.

Ruiz, Alfonso, and S. E. Santander. 20o6. "Y tú de quién eres?” El Diario Montañés, May 7 .

Sann, Paul. 1967. Fads, Follies and Delusions of the American People. New York: Crown. Simpson, Mark. 1998. It's a Queer World:Deviant Adventures in Pop Culture. London: Harrington Park.

Smith, Jim, and Stephen Lavington. 2002. Bond Films. London: Virgin Books.

South Bank Show. 2008. "James Bond Special," https://www.youtube.com/ watch?v=KxtgAuyirmA.

Synnott, Anthony. 1990. "The Beauty Mystique: Ethics and Aesthetics in the Bond Genre." International Journal of Politics, Culture and Society 3, no. 3: 407-26.

Thumim, Janet. 1992. Celluloid Sisters: Women and Popular Cinema. New York: St. Martin's Press.

Tippins, Stephen B., Jr. 2012. “o07's Masculine Mystique.” American Conservative, October 17, http://www.theamericanconservative.com/articles/oo7s-masculinemystique/.

Toffler, Alvin. 1971. Future Shock. New York: Bantam.

Torregrossa, Richard. 2007. "The New Gentleman." The San Francisco Chronicle, February 25, http://www.sfgate.com/living/article/The-New-Gentleman-Stepaside-Mr-Metrosexual-2646133.php.

Tracinski, Robert. 2015. "Why We Need James Bond." The Federalist, November 6, https://thefederalist.com/2015/11/o6/why-we-need-james-bond/.

Travers, Peter. 1997. “Tomorrow Never Dies." Rolling Stone, December 19, http:// www.rollingstone.com/movies/reviews/tomorrow-never-dies-19971219.

The Unlovable James Bond (2016). BFI Films http://www.bfi.org.uk/films-tvpeople/569ce283od $26 \mathrm{~b}$. 
Williams, Zoe, and Paul Flynn. 2006. "The Spy Who Buffed Up." The Guardian, November 16, https://www.theguardian.com/film/2006/nov/16/jamesbond. features.

Young, Derek S. 2019. “Bond. James Bond. A Statistical Look at Cinema's Most Famous Spy." CHANCE 32, no. 1: 27-35.

Yule, Andrew. 1992. Sean Connery: From ooz to Hollywood Icon. New York: Pinnacle. Zakaria, Namrata Sharma. 2004. “The Female Gaze.” Express India, July 4.

\section{About the Author}

Toby Miller is Research Professor of the Graduate Division, University of California, Riverside; Stuart Hall Profesor de Estudios Culturales, Universidad Autónoma Metropolitana-Cuajimalpa; and Professor in the Institute for Media and Creative Industries, Loughborough University London. The author and editor of over forty books, his work has been translated into Spanish, Chinese, Portuguese, Japanese, Turkish, German, Italian, Farsi, French, Urdu, and Swedish. His most recent volumes are How Green Is Your Smartphone? (co-authored, 2020), El Trabajo Cultural (2018), Greenwashing Culture (2018), Greenwashing Sport (2018), The Routledge Companion to Global Cultural Policy (co-edited, 2018), Global Media Studies (co-authored, 2016), The Sage Companion to Television Studies (co-edited, 2015), The Routledge Companion to Global Popular Culture (edited, 2015), Greening the Media (co-authored, 2012), and Blow Up the Humanities (2012). The Persistence of Violence: Colombian Popular Culture is in press. 
